\title{
Inappropriate secretion of antidiuretic hormone in Guillain-Barré syndrome
}

\author{
Aeron G. Davies* \\ M.B., M R C P \\ Medical Registrar \\ Assisted Respiration Unit, Llandough Hospital, Penarth, Glamorganshire
}

\section{Summary}

Hyponatraemia occurred in five cases with severe Guillain-Barré syndrome who required assisted respiration.

In one, the syndrome of inappropriate secretion of ADH was demonstrated and probably accounted for the hyponatraemia in the other four. The water overload thus produced may have contributed to the neurological deterioration and the peripheral and pulmonary oedema seen in some of these cases.

\section{Introduction}

Although the syndrome of inappropriate secretion of antidiuretic hormone (ADH) has been described in acute polyradiculitis of the Guillain-Barré type, this association appears to be rare; seven cases only have been recorded in the literature (Fourman \& Leeson, 1958; Poyart \& Pocidalo, 1964; Cooper, Green \& Wang, 1965; Posner et al., 1967). The object of this communication is to report and discuss the findings in five cases with this syndrome.

\section{Case report}

Case 1. A 63-year-old housewife was admitted to hospital with an 11-day history of an illness beginning with influenza-like symptoms followed later by paraesthesiae and weakness of all limbs. Examination revealed a flaccid quadriplegia and an impairment of all modalities of sensation in a stockingglove distribution. Two days later, lung function tests fell (vital capacity from 3 to $1.6 \mathrm{l}$ ) and she developed bilateral facial nerve palsy, dysphagia and severe respiratory paralysis necessitating tracheostomy. Intermittent positive pressure ventilation (IPPV) was instituted using an East-Radcliffe ventilator with a hot water humidifier in circuit. Fluids were given via a nasogastric tube and intravenous infusion. Blood pressure ranged from 200/140 to $80 / 30 \mathrm{mmHg}$ and skin turgor was normal.

\footnotetext{
* Present address: Senior Registrar, Department of Medicine, Royal Alexandra Hospital, Rhyl, Flints.
}

\section{Investigations and results}

Cerebrospinal fluid protein: $65 \mathrm{mg} / 100 \mathrm{ml}$, no cells seen. Urinary porphyrins absent. Urinary 17hydroxycorticosteroids: $16 \cdot 3 \mathrm{mg} /$ day. Creatinine clearance: $114 \mathrm{ml} / \mathrm{min}$. Blood urea: $34 \mathrm{mg} / 100 \mathrm{ml}$. Results of the balance study performed over a period of 12 days are shown in Fig. 1. Sodium concentrations were measured by flame photometry and osmolalities with a Fiske Osmometer. Despite an intake of 100-200 mEq of sodium, plasma sodium concentration showed a progressive fall on a fluid intake of 3-4 1/day, urinary excretion of sodium continued and there was a positive fluid balance except on Days 2 and 7. Also, plasma osmolality fell but urinary osmolality remained higher than that of the plasma. When fluid intake was restricted to approximately $850 \mathrm{ml} /$ day (Day 8), plasma sodium concentration and osmolality rose despite the marked reduction in sodium intake. A negative fluid balance resulted and urinary excretion of sodium diminished. X-ray of chest revealed pulmonary oedema on Day 6 when the partial pressure of oxygen was only $84 \mathrm{mmHg}$ but this cleared when the pressure rose to $108 \mathrm{mmHg}$ on Day 11. The minute volume and oxygen supplement were the same on these two occasions.

Clinically, the paralysis progressed, the patient became apathetic and developed peripheral oedema during the period of positive water balance. Restriction of fluid intake was associated with neurological recovery and weaning off the ventilator was achieved on Day 14.

\section{Retrospective survey of four other cases}

Hyponatraemia (plasma sodium concentration $130 \mathrm{mEq} / 1$ or less) in all four cases developed with deterioration in the neurological condition. Each developed respiratory failure and dysphagia necessitating tracheostomy and IPPV. Nutrition was maintained via the nasogastric route and on occasions parenterally. One patient's clinical course was complicated by a subarachnoid haemorrhage. Urinary 17-hydroxycorticosteroid and creatinine clearance estimations ruled out the presence of Addison's 

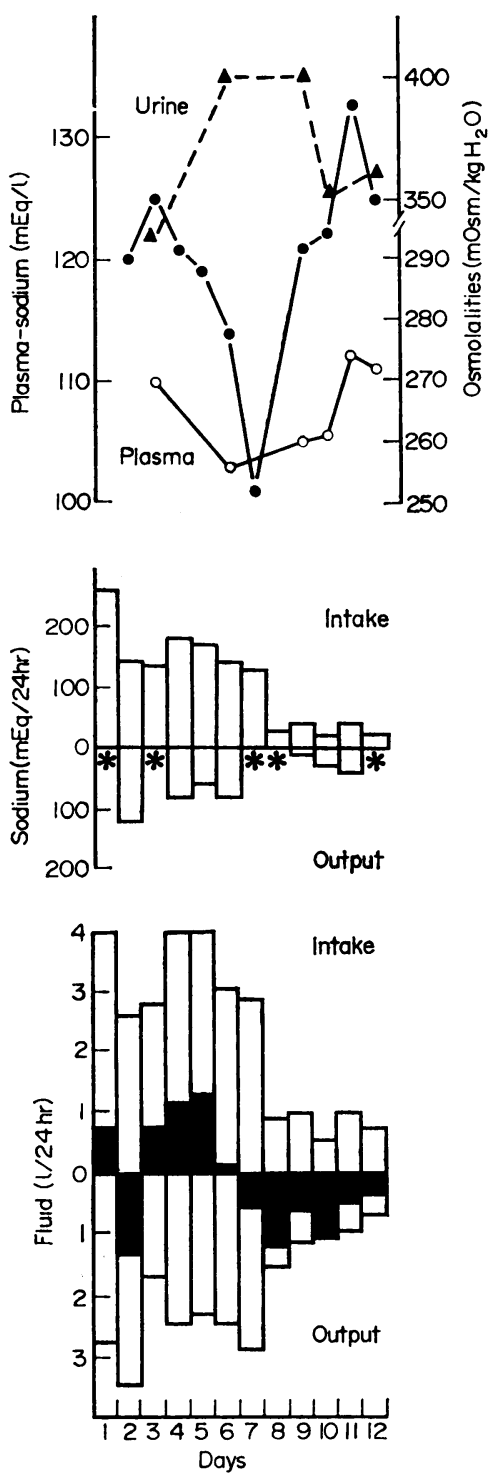

FIo. 1. Case 1. Changes in plasma sodium, plasma and urine osmolalities and urinary sodium and fluid output in relationship to fluid and sodium intake. "Urinary sodium excretion not measured; solid columns, balance of fluid allowing for $500 \mathrm{ml}$ insensible loss. Plasma sodium.

disease and impaired renal function respectively. In all cases the specific gravity of urine did not fall below 1.010 during the period of hyponatraemia, and peripheral oedema was recorded. Pulmonary oedema occurred in three of four patients. All cases made a good recovery and none received steroids.

\section{Discussion}

The syndrome of inappropriate secretion of ADH may be diagnosed if the following criteria are satisfied (Bartter \& Schwartz, 1967):

(1) Hyponatraemia with continued renal excretion of sodium.

(2) Urine osmolality greater than that appropriate for the tonicity of the plasma except during an acute isotonic expansion of the extracellular fluid volume.

(3) Normal renal and adrenal function.

(4) Absence of clinical evidence of fluid volume depletion.

(5) Fluid restriction leads to a rise in plasma sodium concentration and diminished urinary sodium excretion.

Case 1 satisfied these criteria. There was, however, not a good correlation between fluid balance and the degree of fall and rise in plasma sodium concentration, particularly when plasma sodium was less than $115 \mathrm{mEq} / 1$. Bartter \& Schwartz (1967) encountered similar findings and proposed an osmotic inactivation' of intracellular solute to account for this. A retrospective survey of four other patients with hyponatraemia revealed that the specific gravity of their urine did not fall below $1.010\left(330 \mathrm{mOsm} / \mathrm{kgH}_{2} \mathrm{O}\right.$ approximately) when their plasma sodium was less than $130 \mathrm{mEq} / 1 \quad\left(<260 \mathrm{mOsm} / \mathrm{kgH}_{2} \mathrm{O}\right.$ approximately) indicating the inappropriate presence of ADH.

Inappropriate secretion of ADH may be pro-? voked by surgery or anaesthesia (Wynn \& Rob, 1954) and by subarachnoid haemorrhage (Joynt, Afifi \& Harbison, 1965) but not by IPPV (Baratz, Philbin \& Patterson, 1970). In the present series the hyponatraemia developed with and was related to the activity of the polyradiculitis and this has been noted previously (Fourman \& Leeson, 1958; Poyart \& Pocidalo, 1964; Cooper et al., 1965). Case 1 had a plasma sodium concentration of $127 \mathrm{mEq} / \mathrm{l}$ before tracheostomy but the possible potentiating effect of subarachnoid haemorrhage in one of the other cases could not be excluded. The site of the lesion responsible for the inappropriate release of ADH is not known. Posner et al. (1967) considered either a central lesion in the limbic-supraoptic-hypophyseal system, or a peripheral one affecting the glossopharyngeal and vagus nerves which convey impulses from stretch receptors in the left atrium, carotid sinus and aortic arch known to influence ADH secretion. The peripheral lesion was favoured because of lack of histological confirmation of hypothalamic pathology (Haymaker \& Kernohan, 1949). In the present series vagus nerve involvement was a feature common to all cases as evidenced by dysphagia and loss of palatal reflex.

The progressive fall in sodium concentration due to retention of fluid in Case 1 was accompanied by 
mental apathy and an increase in paralysis which improved on restricting fluid. A vicious circle seems to develop in acute polyradiculitis. When the paralysis is most severe, disturbance of salt and water balance is most marked and an excess intake of water causes further neurological deterioration and may perpetuate the paralysis. The occurrence of pulmonary oedema in Guillain-Barré syndrome has not been commented on previously except at necropsy (Haymaker \& Kernohan, 1949) and in one case by Sladen, Laver \& Pontoppidan (1968) which they attributed to IPPV. However, inappropriate secretion of ADH has not been shown to occur as a result of IPPV (Baratz et al., 1970). Pulmonary oedema was witnessed in four of the five cases reported here. It is suggested that inappropriate secretion of $\mathrm{ADH}$ with its resultant fluid overload probably contributed to the development of pulmonary oedema in these cases. This would also explain the peripheral oedema seen in all the five cases and in others previously reported (Spalding \& Crampton Smith, 1963; Bendixen et al, 1965; Poyart \& Pocidalo, 1964) although circulatory stasis due to immobility and sympathetic paralysis may have played a part.

Hyponatraemia in association with acute polyradiculitis has been commented on by other investigators (Schaltenbrand \& Steger, 1951; Hewer et al., 1968); inappropriate secretion of ADH may thus complicate this disease more frequently than is realized. Posner et al (1967) considered that water overload contributed to the death of two patients in their series. Patients with acute polyradiculitis should, therefore, have their plasma-sodium concentrations carefully monitored, and the significance of hyponatraemia appreciated. It is easy to give too much water to patients fed via a nasogastric tube or intravenously. In the Guillain-Barré syndrome a 'normal' intake of water may prove fatal.

\section{Acknowledgments}

I am indebted to Dr A. H. El-Shaboury for detailed criticism, to Dr D. A. Williams and Dr H. E. F. Davies for advice, to Dr J. Picton Thomas for measurement of osmolalities and to Dr J. Donald Ball and Dr H. R. Dingle for allowing me to study patients under their care and for encouragement.

\section{References}

Baratz, R.A., Philbin, D.M. \& Patterson, R.W. (1970) Urinary output and plasma levels of antidiuretic hormone during intermittent positive-pressure breathing in the dog. Anesthesiology, 32, 17.

BARTTER, F.C. \& SchwarTz, W.B. (1967) The syndrome of inappropriate secretion of antidiuretic hormone. American Journal of Medicine, 42, 790.

BendiXen, H.H., Egbert, L.D., Hedley-Whyte, J., LAVER, M.B. \& Pontoppidan, H. (1965) Respiratory Care, p. 178. C. V. Mosby and Co., St Louis.

CoOper, W.C., Green, I.J. \& Wang, S.P. (1965) Cerebral salt-wasting associated with the Guillain-Barré syndrome. Archives of Internal Medicine, 116, 113.

Fourman, P. \& LeEson, P.M. (1958) Hypernatraemia and hyponatraemia with special reference to cerebral disturbances. In: Ciba Foundation Colloquia on Ageing, Vol. 4 -Water and electrolyte metabolism in relation to age and sex (Ed. by G. E. W. Wolstenholme and M. O'Connor), p. 36. J. \& A. Churchill, London.

HAYMAKER, W. \& KERNOHAN, J.W. (1949) Landry-GuillainBarré syndrome; clinicopathologic report of fifty fatal cases and critique of literature. Medicine, $28,59$.

Hewer, R.L., Hilton, P.J., Crampton Smith, A. \& SpaldING, J.M.K. (1968) Acute polyneuritis requiring artificial respiration. Quaterly Journal of Medicine, 37, 479.

JoYNT, R. J., AFIFI, A. \& HARBISON, J. (1965) Hyponatremia in sub-arachnoid hemorrhage. Archives of Neurology, 13, 633.

Posner, J.B., Ertel, N.H., KossmanN, R.J. \& Scheinberg, L.C. (1967) Hyponatremia in acute polyneuropathy. Archives of Neurology, 17, 530.

PoyarT, C. \& Pocidalo, J.J. (1964) Hyponatrémie avec natriurie conservée par trouble de l'élimination de l'eau libre au cours d'un syndrome de Guillain-Barré. Revue française d'études Cliniques et Biologiques, 9, 1068.

Schaltenbrand, G. \& Steger, J. (1951) Serose Polyneuritis und hepatorenales Syndrom. Deutsches Archiv für klinische Medizin, 198, 673.

Sladen, A., Laver, M.B. \& Pontoppidan, H. (1968) Pulmonary complications and water retention in prolonged mechanical ventilation. New England Journal of Medicine, 279, 448.

Spalding, J.M.K. \& CRAmpton Smith, A. (1963) Clinical Practice and Physiology of Artificial Respiration, p. 99. Blackwell Scientific Publications, Oxford.

WYNN, V. \& ROB, C.G. (1954) Water intoxication: differential diagnosis of hypotonic syndromes. Lancet, i, 587. 